Portland State University

PDXScholar

Psychology Faculty Publications and

Presentations

Psychology

6-16-2021

\title{
Critical Points in Lemke's Total Worker Health Calculus.
}

\author{
Kevin M. Kelly \\ University of lowa \\ Lee S. Newman \\ Colorado School of Public Health \\ Martin Cherniack \\ UConn Health \\ Laura Punnett \\ University of Massachusetts \\ Leslie B. Hammer \\ Portland State University, hammerl@pdx.edu
}

See next page for additional authors

Follow this and additional works at: https://pdxscholar.library.pdx.edu/psy_fac

Part of the Psychology Commons

Let us know how access to this document benefits you.

\section{Citation Details}

Kelly, K. M., Newman, L. S., Cherniack, M., Punnett, L., Hammer, L. B., \& Sorensen, G. (2021). Critical Points in Lemke's Total Worker Health Calculus. Journal of Occupational \& Environmental Medicine, Publish Ahead of Print. https://doi.org/10.1097/jom.0000000000002300

This Post-Print is brought to you for free and open access. It has been accepted for inclusion in Psychology Faculty Publications and Presentations by an authorized administrator of PDXScholar. Please contact us if we can make this document more accessible: pdxscholar@pdx.edu. 
Authors

Kevin M. Kelly, Lee S. Newman, Martin Cherniack, Laura Punnett, Leslie B. Hammer, and Glorian Sorensen 
Journal of Occupational and Environmental Medicine, Publish Ahead of Print

DOI : 10.1097/JOM.0000000000002300

\section{Critical Points in Lemke's Total Worker Health Calculus}

Kevin M. Kelly $\mathrm{PhD}^{1}$, Lee S. Newman MD, $\mathrm{MA}^{2}$, Martin Cherniack MD, $\mathrm{MPH}^{3}$, Laura Punnett $\mathrm{ScD}^{4}$, Leslie B. Hammer $\mathrm{PhD}^{5}$, Glorian Sorensen $\mathrm{PhD} \mathrm{MPH}^{6}$

${ }^{1}$ Deputy Director, Healthier Workforce Center of the Midwest, Associate Research Scientist, Department of Occupational and Environmental Health, Adjunct Associate Professor of Anthropology, University of Iowa, Iowa City, IA

${ }^{2}$ Center Director, Center for Health, Work \& Environment, Distinguished University Professor, Colorado School of Public Health, CU Anschutz Medical Campus, Aurora, CO

${ }^{3}$ Co-Director, Center for the Promotion of Health in the New England Workplace (CPHNEW), Professor of Medicine, UConn Health, Farmington, CT

${ }^{4}$ Co-Director, Center for the Promotion of Health in the New England Workplace (CPHNEW), Professor of Epidemiology and Occupational Ergonomics, University of Massachusetts Lowell, Lowell, MA

${ }^{5}$ Co-Director, Oregon Healthy Workforce Center, Professor, Oregon Institute of Occupational Health Sciences, Oregon Health \& Science University; Professor of Psychology, Portland State University, Portland, OR

${ }^{6}$ Director, Harvard Chan School Center for Work, Health and Wellbeing, Professor of Social and Behavioral Sciences, Harvard School of Public Health, Boston, MA

Address correspondence to Kevin M. Kelly, 3498 Laurel Ln, Marion, IA 52302 (kevinkelly@uiowa.edu)

\section{Conflicts of interest: None.}

Funding: In full transparency, the authors acknowledge support, in part or in whole, from Cooperative Agreements from the Centers for Disease Control and Prevention (CDC) / National Institute for Occupational Safety and Health (NIOSH) (U19OH008868, U19OH011227, U19OH008857, U19OH010154, and U19OH008861). The contents are solely the responsibility of the authors and do not necessarily represent the official views of the CDC, NIOSH, or the authors' respective institutes. 


\section{To the editor:}

In his recent editorial, Michael Kenneth Lemke makes the assertion that shortcomings within the Total Worker Health [TWH] program are due to its theoretical and methodological grounding in the "Newtonian paradigm." According to Lemke, the long-term potential of the TWH program is threatened by the hegemony of reductionism. ${ }^{1}$ We assert that Lemke's reasoning, and therefore, his conclusions are flawed. Moreover, we believe that his characterization does little to promote, and may hinder, the ability of the TWH program to fulfill its mission.

Lemke's freestyle reasoning is replete with formal and informal logical fallacies that are so common that they have names (e.g., false premise ${ }^{2}$, incomplete comparison ${ }^{3}$, non sequitor ${ }^{4}$, Straw Man $^{5}$, cherry picking ${ }^{6}$, Texas sharpshooter ${ }^{7}$ ). In fact, the editorial's deficient reasoning and inadequate substantiation are so glaring that several of us initially suspected the editorial was a scholarly publishing sting-a hoax not unlike the Sokal Affair ${ }^{8}$--submitted to test the journal's intellectual rigor. However, the discovery of prior criticism ${ }^{9}$ suggest that this display is simply added posturing.

For example, in Lemke's editorial, his criticism of TWH begins with the premise that

"As is true of the social sciences in general, the epistemology of TWH is grounded in theoretical and methodological assumptions and approaches that are representative of what may be called a 'Newtonian paradigm.'”

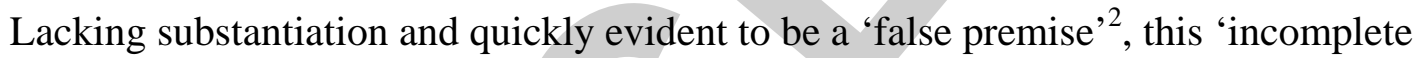
comparison, ${ }^{3}$ is followed by this assertion:

"Within [the Newtonian] paradigm, phenomena of interest-such as $\mathrm{OSH}$ outcomes_-are assumed to be deterministic, mechanistic, and predictable.”

A non sequitur ${ }^{4}$, this claim is supported by citing the works of Louth ${ }^{10}$, Haupt $^{11}$, and Gershenson $^{12}$ [Lemke's references 9, 10 and 11]. Here again, Lemke misses his mark as none of the three citations suggest that OSH outcomes or, for that matter, the social sciences after World War I, are grounded in a 'Newtonian paradigm.' So, while true that Newtonian outcomes are “deterministic, mechanistic, and predictable,” Lemke fails to establish a plausible connection to the TWH paradigm or current social sciences methods. Consequently, the validity of any conclusions based on that premise remains in question. ${ }^{12}$

Undeterred, Lemke continues to attack his Straw Man ${ }^{5}$ using cherry-picked ${ }^{6}$ examples in an attempt to convince readers that he has hit his mark (known coincidently as the Texas sharpshooter fallacy ${ }^{7}$ ). Clearly, he has not. 
While a rebuttal of Lemke's editorial, this response should not be read as a blanket defense of the TWH program. TWH has been evolving for more than a decade ${ }^{13}$ and will continue to evolve to address the complex challenges we face today and as the future of work unfolds. ${ }^{14}$ We agree that any system must be open for incremental change and reconsideration. However, any discussion of possible shortcomings or potential improvements within the TWH program should be rational and objective. We encourage JOEM readers to consider the body of TWH research, practical tools, and educational offerings to see where the field has been and where it is headed, to promote the health, safety, and well-being of workers. ${ }^{15}$

\section{References}

1. Lemke MK. Is the Total Worker Health Program Missing Its Mark? Integrating Complex Systems Approaches to Unify Vision and Epistemology. JOEM 2021;63(5):e304-e307.

2. False premise [Wikipedia website] Available at https://en.wikipedia.org/wiki/False_premise Accessed 20 May 2021

3. Incomplete comparison [Wikipedia website] Available at https://en.wikipedia.org/wiki/Incomplete_comparison Accessed 20 May 2021

4. Non sequitur [Wikipedia website] Available at https://en.wikipedia.org/wiki/Formal_fallacy Accessed 20 May 2021

5. Bluedorn N, Bluedorn H. The Fallacy Detective ( $4^{\text {th }}$ Edition). Christian Logic; 2015, $264 \mathrm{pp}$.

6. Devious deception in displaying data: Cherry picking [Science or Not website]. April 3, 2012, Available at https://scienceornot.net/2012/04/03/devious-deception-indisplaying-data-cherry-picking/ Accessed 16 May 2021

7. Bennett B. Texas sharpshooter fallacy [Logically Fallacious website] Available at https://www.logicallyfallacious.com/logicalfallacies/Texas-Sharpshooter-Fallacy Accessed 16 May 2016

8. Sokal Affair [Wikipedia website] Available at https://en.wikipedia.org/wiki/Sokal_affair Accessed 18 May 2021

9. Lemke M, Apostolopoulos Y, Sonmez S, Caban-Martinez AJ. How complex systems approaches can advance the total worker health program. [APHA's 2020 VIRTUAL Annual Meeting and Expo (Oct. 24 - 28) website] October 27, 2020, Available at https://apha.confex.com/apha/2020/meetingapp.cgi/Paper/470959 Accessed 20 May 2021

10. Louth J. From Newton to Newtonianism: reductionism and the development of the social sciences. Emerg Complex Org. 2011;13:63-83.

11. Haupt J. Applying Complexity Science to Health and Healthcare. Minneapolis: Plexus Institute; 2003

12. Gershenson C. The implications of interactions for science and philosophy. Found Sci. 2013;18:781-790. 
13. Weston A. A Rule Book for Arguments ( $4^{\text {th }}$ Edition). Indianapolis: Hackett; 2009:1922.

14. Tamers S, Chosewood L, Childress A, Hudson H, Nigam J, Chang C. Total Worker Health ${ }^{\circledR}$ 2014-2018: The Novel Approach to Worker Safety, Health, and Well-Being Evolves. Int J Environ Res Public Health 2019; 16(3):321; https://www.mdpi.com/1660-4601/16/3/321

15. National Institutes for Occupational Safety and Health. NIOSH Future of Work Initiative. April 2, 2020. Available at https://www.cdc.gov/niosh/topics/future-ofwork/default.html Accessed 17 May 2021.

16. National Institutes for Occupational Safety and Health. NIOSH Total Worker Health ${ }^{\circledR}$ Program. July 28, 2020. Available at https://www.cdc.gov/NIOSH/twh/ Accessed 17 May 2021. 